\title{
ASSESSMENT AND IMPROVEMENT OF HYGIENIC STATUS OF CHICKEN FILLET FROM SLAUGHTERHOUSES USING ORGANIC ACIDS FROM NATURAL SOURCES
}

\author{
KHALED, M. EL-KHAWAS and BASEMA A. S. HENDY \\ Animal Health Research Institute, Agriculture Research Center, Dokki, Giza
}

Email: kkhwas@yahoo.com

Assiut University web-site: www.aun.edu.eg

\section{ABSTRACT}

Received at: 15/8/2015

Accepted: 6/9/2015
This study was conducted firstly to investigate the bacteriological status of chicken fillet produced in poultry slaughterhouses and secondly to improve its safety at the home level during preparation for cooking using vinegar or lemon juice as a natural source for organic acids. Sixty samples of chicken fillet, (30 each of breast and thigh) were collected from slaughterhouses. Mean aerobic plate and coliforms counts for thigh samples (4.41 and $1.83 \log \mathrm{cfu} / \mathrm{g}$ ) were significantly higher $(\mathrm{P}<0.01)$ than that of breast samples $(3.89$ and $1.42 \mathrm{log} \mathrm{cfu} / \mathrm{g})$. Each of Salmonella Typhimurium and $S$. aureus were isolated from $3.3 \%$ of samples, meanwhile, E. coli was detected in $30 \%$ and $10 \%$ of thigh and breast samples, respectively. Accordingly, $36.7 \%$ and $80.0 \%$ of thigh and breast samples, respectively were compatible with the Egyptian standards. Dipping of chicken fillet in vinegar or lemon juice ( $2 \%$ acetic or citric acids) for 25 min reduced the aerobic plate count by one $\log \mathrm{cfu} / \mathrm{g}$ and $S$. aureus by $2 \mathrm{log} \mathrm{cfu} / \mathrm{g}$ without significance difference $(\mathrm{P}>0.05)$ between them. On the other hand, lemon juice significantly reduced salmonella ( 2 $\log \mathrm{cfu} / \mathrm{g})$ and $E$. coli $(3 \mathrm{log} \mathrm{cfu} / \mathrm{g}$ ) counts one $\log$ more than vinegar (1 and $2 \mathrm{log}$ $\mathrm{cfu} / \mathrm{g}$ for each of them, respectively).

Key words: Chicken fillet, E. coli, S. aureus, Salmonella, vinegar, lemon juice

\section{INTRODUCTION}

Food-borne diseases, caused by agents that enter the body through the intake of contaminated food materials are one of the primary public health concerns (Tan et al., 2013). Epidemiological reports suggest that poultry meat is still the primary cause of human food poisoning (Mulder, 1999). Poultry and poultry products rank first or second in foods associated with disease in most of the countries all over the world (Bean and Griffin, 1990). Unhygienic practices, use of contaminated instruments and materials in food processing are mainly associated with food-borne diseases (Wilfred et al., 2012). An effective way of preventing food-borne human diseases is to monitor the microbiological quality of poultry meat and meat products during production, storage and distribution. Monitoring of foodborne pathogens in food products are the only means to cope with the problem promptly (Chang et al., 2013). Microflora of raw chicken meat is heterogeneous and originates from slaughtering premises, operators' hands, equipment and outfit, and water and air (Fries, 2002). In addition to pathogenic bacteria, special attention in the hygienic production and storage of chicken meat is paid also to total count of aerobic mesophilic bacteria, enterobacteria and Escherichia coli. These bacteria are considered indicators of microbiological quality (Capita et al., 2002), which give an idea about the hygienic measures during further processing and help in assessing the keeping quality of further processed chicken meat products (Aberle et al., 2001).

Foodborne Salmonellosis is important public health problem in many parts of the world, causing gastrointestinal illness, substantial morbidity, and hospitalization and economic burden worldwide (Fearnley et al., 2011). The Salmonella serovars most frequently isolated from humans are Salmonella Typhimurium and Salmonella Enteritidis, the last is the most prevalent global serovar of Salmonella (Hassanein et al., 2011). The primary reservoir of Salmonella is the intestinal tract of animals and birds, which contaminate the muscles and organs during slaughtering (Paiao et al., 2013). Poultry and poultry products are the most potential source of Salmonella food poisoning in man (Lynch et al., 2006), that can be transmitted to humans through the handling of raw products, or through consumption of undercooked poultry meat (Kimura et al., 2004). 
E. coli is responsible for $25 \%$ of the infant diarrhoea in developing countries (WHO, 2000). Shiga toxin producing $E$. coli (STEC) was first recognized as a human pathogen in 1982 in the USA when strains of serotype O157:H7 caused two outbreaks of hemorrhagic colitis (Wells et al., 1983). Its presence in food materials are considered to be an indicator for the presence of other pathogenic bacteria in the respective food items (Shar et al., 2010).

Staphylococcus aureus is a significant cause of avian disease and may thus contaminate foods as a result of processed carcasses (Mead and Dodd, 1990). Enterotoxin-producing $S$. aureus is the most common cause of food-borne human illness throughout the world (Do Carmo et al., 2004). The foods that most frequently cause this type of poisoning are red meat and poultry and their products (Kitai, 2005). While staphylococci commonly occur on the skin and nasopharynx of healthy poultry (Mead and Dodd, 1990), it is primarily S. aureus which can survive, colonize, and persist at various processing stages in commercial poultry processing plants due to the expression of various key properties, including adhesion and chlorine resistance (Huys, 2005). Monitoring of $S$. aureus is important for both of the evaluation of safety and hygienic quality of chicken meat, and also in the aetiology of food poisoning (Jablonski and Bohach, 1997).

Chemical decontamination was first used in the 1960s and contributed to the control of food pathogens (Acuff, 2005). There is an increasing interest in applying natural antimicrobial compounds in the food industry as consumers are increasingly avoiding the consumption of foods treated with chemicals. This creates new challenges in providing efficient food preservation, especially in the area of microbial safety (Suppakul et al., 2003). Organic acids are popular because of the lack of toxicological implications when applied at the prescribed concentrations. U.S. Department of Agriculture (2008) states that acetic and citric acids are generally recognized as safe substances (GRAS) and is allowed in or on processed products labeled as organic. Application of organic acids on meat surfaces is a common procedure; acid treatments are cheap, simple and fast, and have shown clear efficiency (Hinton and Corry, 1999).

Citric and acetic acids have been used for years for decontamination of bacteria on beef, pork, and poultry (Mani-Lopez et al., 2012). Using of lemon juice or vinegar in food (as salads) provide a harsh environment for foodborne pathogens such as Salmonella and E. coli to survive because of the acetic or citric acids (Beuchat et al., 2006). Acetic acid is the active ingredient of house-hold vinegar has been tested and approved as dipping or spraying treatments. Normal white household vinegar consists of a concentration of approximately $5 \%$ acetic acid. When this diluted to at least $2 \%$ it is actually recommended as a preservative (Mani-Lopez et al., 2012). However, the use of acetic acid might be limited due to their flavor and taste, diluted solutions of organic acids (1-3\%) are generally without effect on the desirable sensory properties of meat (Min et al., 2007).

After appearance of avian influenza and as a preventive measure the government restricted transmission of life chicken between governorates and encouraged establishment of poultry slaughterhouses, consequently many new slaughterhouses appeared. Therefore, this study aimed to investigate the bacteriological status of chicken fillet produced in slaughterhouses and the use of vinegar and lemon juice as natural sources of acetic and citric acids to improve its safety at the home level during preparation for cooking.

\section{MATERIALS and METHODS}

\section{First part: Survey of chicken fillet from slaughterhouses}

Sample Collection: A total of 60 samples of chicken skin less fillet from slaughterhouses, 30 each of breast and thigh meat, were collected and transported to the laboratory in ice box without due delay to be examined bacteriologically. Homogenate of each sample $\left(10^{-1}\right)$ was prepared by buffered peptone to perform aerobic plate count (APC) and coliform count $\mathrm{cfu} / \mathrm{g}$, in addition, detection of Escherichia coli, Staphylococcus aureus and Salmonella species were performed according to APHA (2001).

\section{Second part: Decontamination using lemon juice and vinegar}

S. aureus (ATCC 29213), Salmonella Typhimurium (ATCC 14028) and Escherichia coli (ATCC 8739) strains (acquired from the Department of Food hygiene, Animal Health Research Institute, Dokki, Giza) from frozen cultures were activated with two successive passes in $9 \mathrm{ml}$ of tryptic soy broth (TSB) (Oxoid) and incubated at $37^{\circ} \mathrm{C}$ for $18 \mathrm{~h}$. For each individual strain, $1 \mathrm{ml}$ of the stock inoculum was added to $100 \mathrm{ml}$ of TSB and incubated with shaking at $37^{\circ} \mathrm{C}$ for $18-24 \mathrm{~h}$, then further diluted to reach a final concentration of approximately $5 \log \mathrm{cfu} / \mathrm{mL}$ (determined by plating on specific media). Then, 2.5 $\mathrm{ml}$ of the stock inoculum was added to $250 \mathrm{ml}$ of sterilized saline to give final concentration of approximately 3 to $4 \log \mathrm{CFU} / \mathrm{mL}$ in the dipping solution. Chicken fillet (previously tested to be free of concerned microorganisms) were inoculated by being placed for $20 \mathrm{~s}$ in the dipping solution followed by drying under a hood at least $20 \mathrm{~min}$ to allow attachment of bacteria (Corry et al., 2007). 
Acetic and citric acids $2 \%$ from vinegar (5\% acetic acid) and lemon juice (4.5\% citric acid), respectively, were prepared for acid treatments. Each one of the inoculated chicken fillet was placed separately in the dipping solution (at ambient temperature) for 5, 10, 15,20 or $25 \mathrm{~min}$.

Bacterial count: The acid-treated and non-treated chicken fillet were counted on selective media for each strain (Baird Parker for $S$. aureus, XLD for $S$. Typhimurium and EMB, for E. coli) in duplicate to determine the initial count before treatment and after treatment with the organic acids. Twenty-five grams of chicken fillet were placed in a stomacher bag with $225 \mathrm{ml}$ of $0.1 \%$ peptone water and stomached for 1 min. Serial dilutions were prepared, spread plated in duplicate on selective media for each strain and incubated at $35^{\circ} \mathrm{C}$ for $24-48 \mathrm{~h}$. Colonies were enumerated, and the cfu/g was calculated.

Chicken fillet samples (from first part) proved to be exceeding the permissible limit of aerobic plate count (8 samples) according to the Egyptian standards were treated and recounted as inoculated microorganisms.

Statistical analysis: Data were analyzed by using mixed procedure from SPSS software (release 20, IBM CO) after logarithmic transformation for bacteriological count. A completely randomized design was selected in the second part. The experiment was conducted in three repetitions. Means were separated by T-test, and significance was tested at $\alpha=0.05$.

\section{RESULTS}

Part I: survey of chicken fillet from slaughterhouse

Table 1: Statistical analysis of bacterial counts $(\log \mathrm{cfu} / \mathrm{g})$ in examined samples

\begin{tabular}{|c|c|c|c|c|c|c|c|c|}
\hline Bacterial count & \multicolumn{4}{|c|}{ APC } & \multicolumn{4}{|c|}{ Coliforms } \\
\hline Samples & \multicolumn{2}{|c|}{ Thigh } & \multicolumn{2}{|c|}{ Breast } & \multicolumn{2}{|c|}{ Thigh } & \multicolumn{2}{|c|}{ Breast } \\
\hline Minimum & \multicolumn{2}{|c|}{3.30} & \multicolumn{2}{|c|}{2.95} & \multicolumn{2}{|c|}{1.00} & \multicolumn{2}{|c|}{0.56} \\
\hline Maximum & \multicolumn{2}{|c|}{5.90} & \multicolumn{2}{|c|}{5.00} & \multicolumn{2}{|c|}{3.38} & \multicolumn{2}{|c|}{3.04} \\
\hline Mean $\pm \mathrm{SE}$ & \multicolumn{2}{|c|}{$4.41 \pm 0.16^{\mathrm{A}}$} & \multicolumn{2}{|c|}{$3.89 \pm 0.12^{\mathrm{a}}$} & \multicolumn{2}{|c|}{$1.83 \pm 0.12^{\mathrm{B}}$} & \multicolumn{2}{|c|}{$1.42 \pm 0.13^{b}$} \\
\hline Compatibility & No. & $\%$ & No. & $\%$ & No. & $\%$ & No. & $\%$ \\
\hline Less than limit & 22 & $73 \%$ & 30 & $100 \%$ & 19 & $63 \%$ & 26 & $87 \%$ \\
\hline More than limit & 8 & $27 \%$ & 0 & $0 \%$ & 11 & $37 \%$ & 4 & $13 \%$ \\
\hline
\end{tabular}

There are significance differences between means have same capital and small litter $(\mathrm{P}<0.01)$ for the same count.

Table (1) revealed the statistical analysis of bacterial counts of examined samples. Mean aerobic plate count for thigh samples $(4.41 \log \mathrm{cfu} / \mathrm{g})$ was significantly higher $(\mathrm{P}<0.01)$ than breast samples (3.89 $\log \mathrm{cfu} / \mathrm{g}$ ). Also coliforms count for thigh samples (1.83 log cfu/g) was significantly higher $(\mathrm{P}<0.01)$ than breast samples $(1.42 \log \mathrm{cfu} / \mathrm{g})$. Concerning the compatibility with the Egyptian standards (2005), $27 \%$ of thigh samples was more than the aerobic count stated by the standard (5 log cfu/g); meanwhile all breast samples were within this limit. On the other hand, for coliforms count, $37 \%$ and $13 \%$ of thigh and breast samples respectively were more than the accepted limit stated in the standard $(2 \log \mathrm{cfu} / \mathrm{g})$.

Fig. (1) illustrate the incidence of isolation of $S$. aureus, Salmonella and E. coli and final fitness of samples according to bacterial counts and isolation comparing to the Egyptian standards. S. aureus was isolated from one sample only $(3.3 \%)$ of breast but failed to be detected from any sample of thigh. On the contrary, Salmonella was isolated from one sample only from thigh $(3.3 \%)$ (Salmonella Typhimurium) but failed to be detected from any sample of breast. On the other hand, E. coli was detected in 9 samples of thigh (30\%) and 3 samples of breast (10\%). 


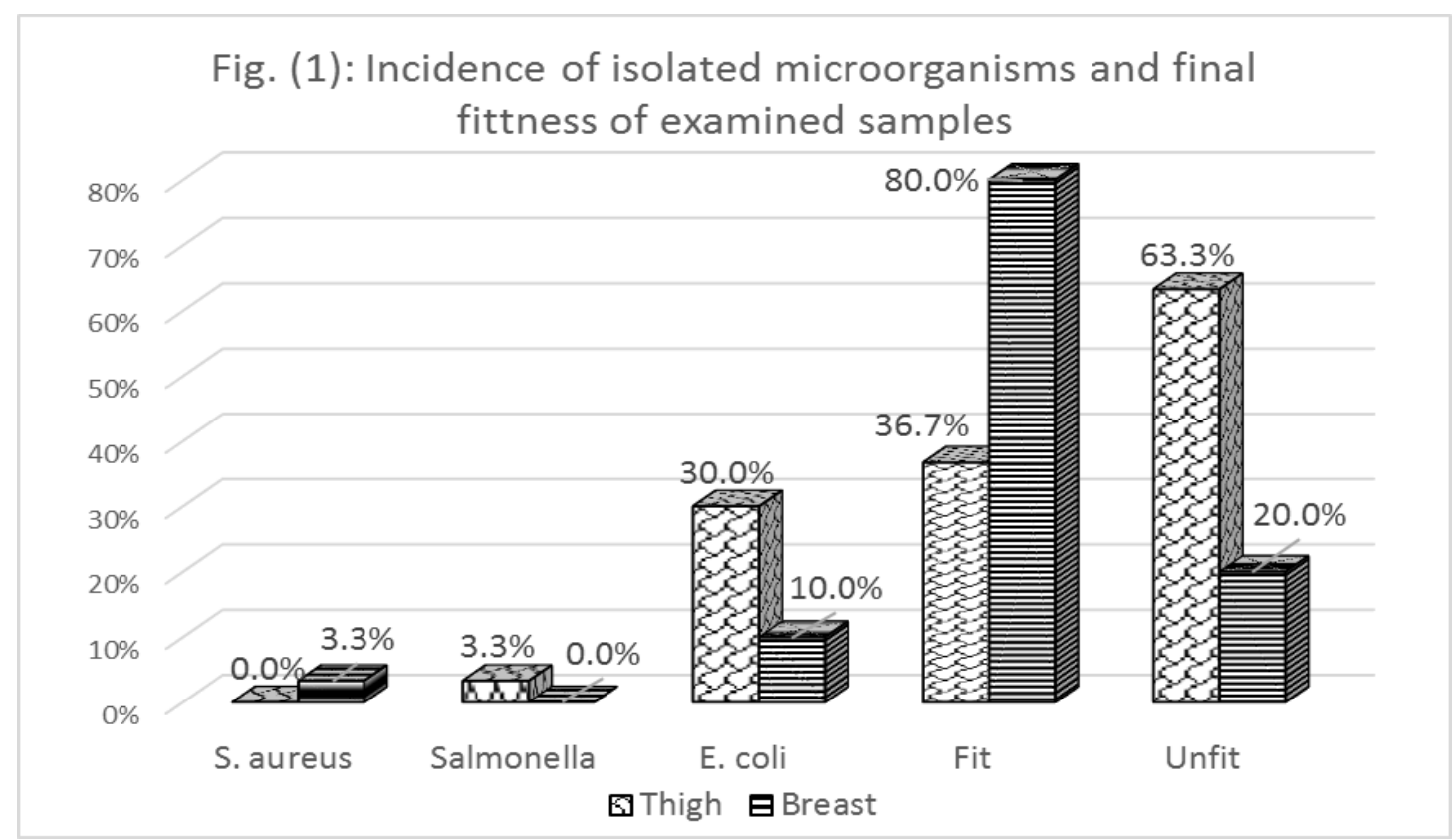

The overall fitness of samples according to microbial counts and isolation of food poisoning microorganisms in competence with the Egyptian standards was 11 samples $(36.7 \%)$ in thigh and 24 samples $(80.0 \%)$ in breast.

Part II: effect of citric and acetic acids on improvement of chicken fillet

Prior to treatment with organic acids, the mean initial APC was $5.8 \log \mathrm{cfu} / \mathrm{g}$ (Fig. 2), which slowly decreased after dipping in each of the two treatments. The reduction reached $0.5 \mathrm{log} \mathrm{cfu} / \mathrm{g}$ after dipping for $20 \mathrm{~min}$, but after $25 \mathrm{~min}$, the count decreased by one $\log$. There was no significance difference $(\mathrm{P}>0.05)$ between the two treatments at the same dipping time.

The initial count of $S$. aureus inoculated on the chicken fillet (Fig. 3), was $3.3 \mathrm{log}$ cfu/g, which didn't reduced even after dipping in acid solutions for 5 min. After $10 \mathrm{~min}$ of dipping of the inoculated fillet, the count begin to be reduced slowly. On the contrary, the count was sharply reduced by $2 \operatorname{logs}$ after $20 \mathrm{~min}$ of treatment without significance difference $(\mathrm{P}>0.05)$ between the two treatments.

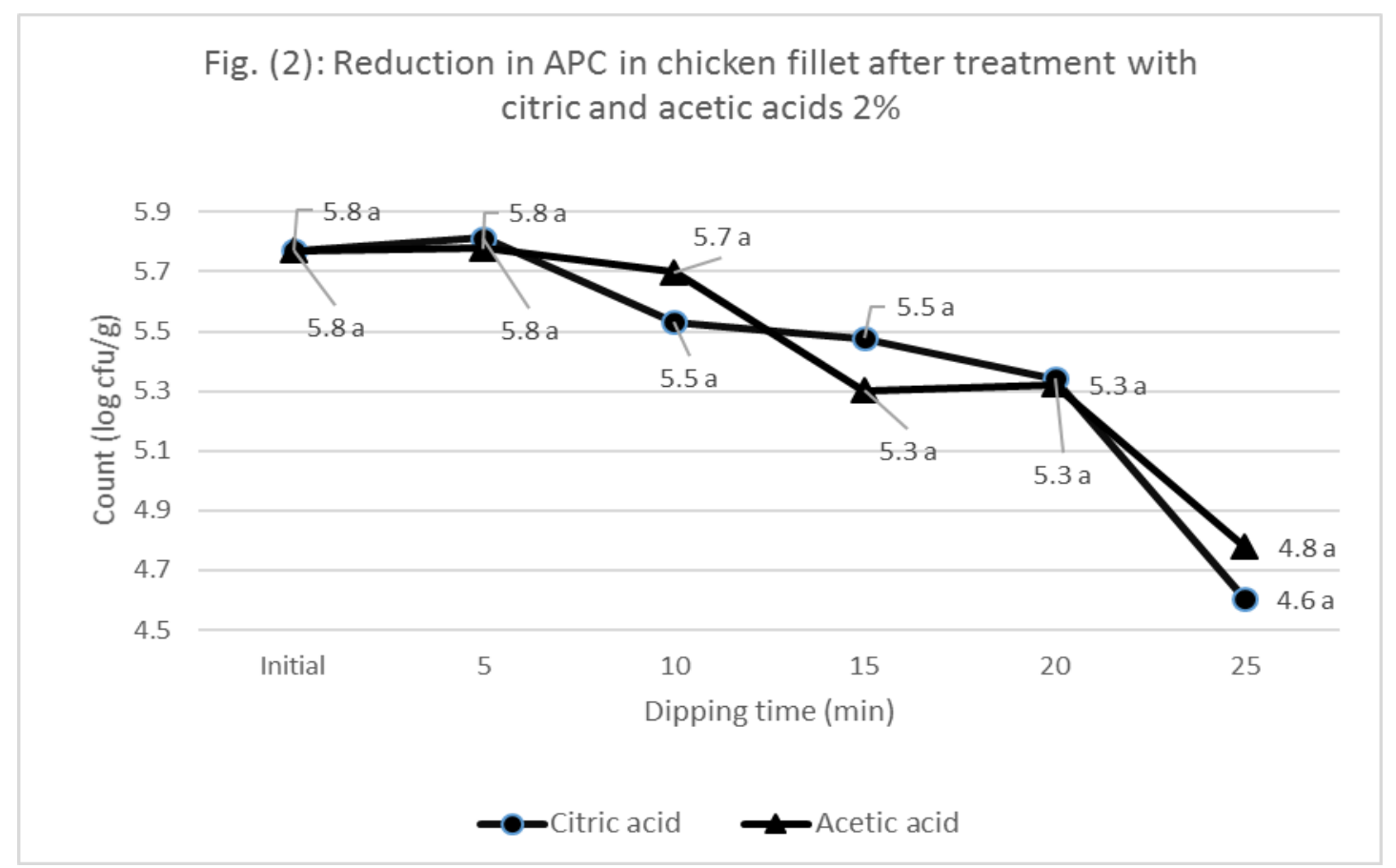

There are significance differences between means have same capital and small litter $(\mathrm{P}<0.01)$ for the same time. 


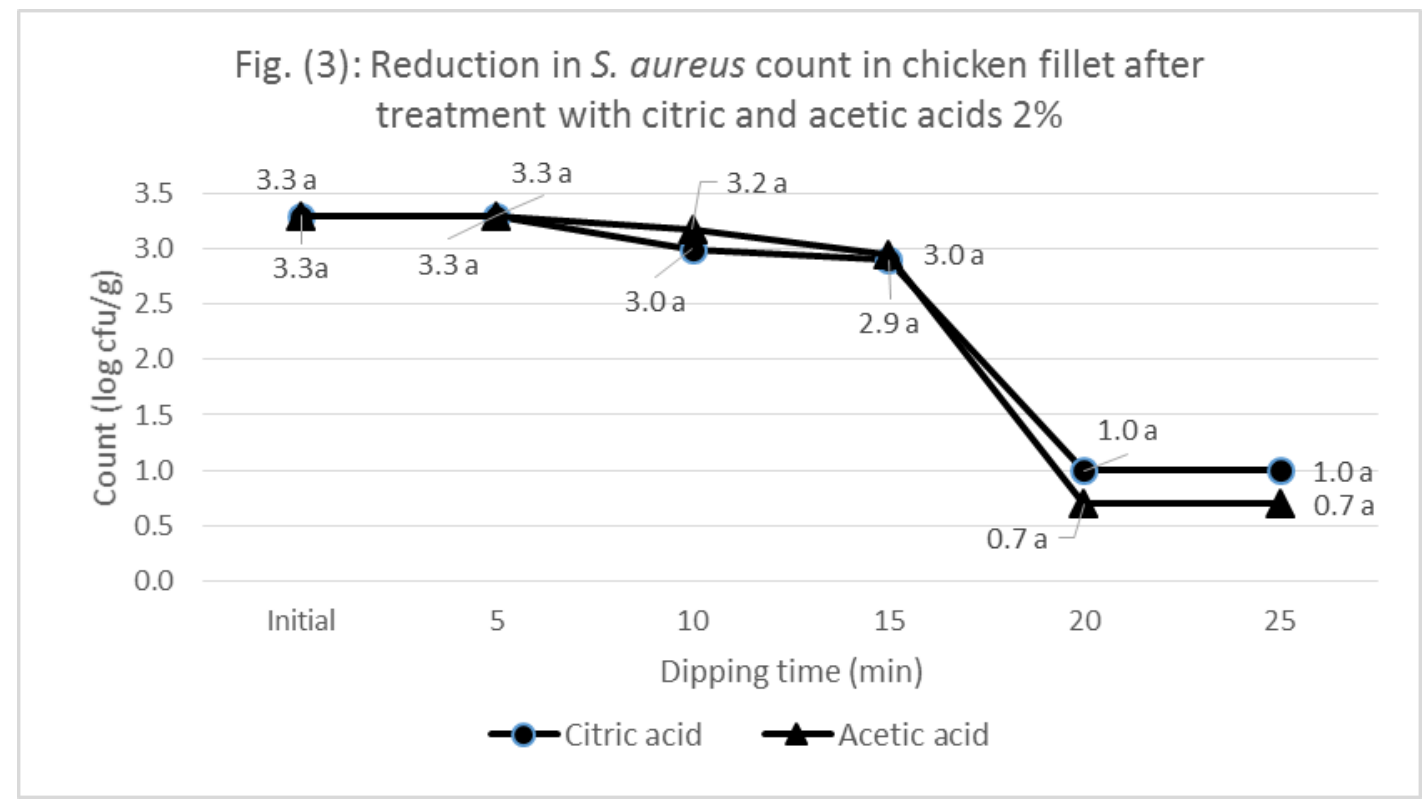

There are significance differences between means have same capital and small litter $(\mathrm{P}<0.01)$ for the same time.

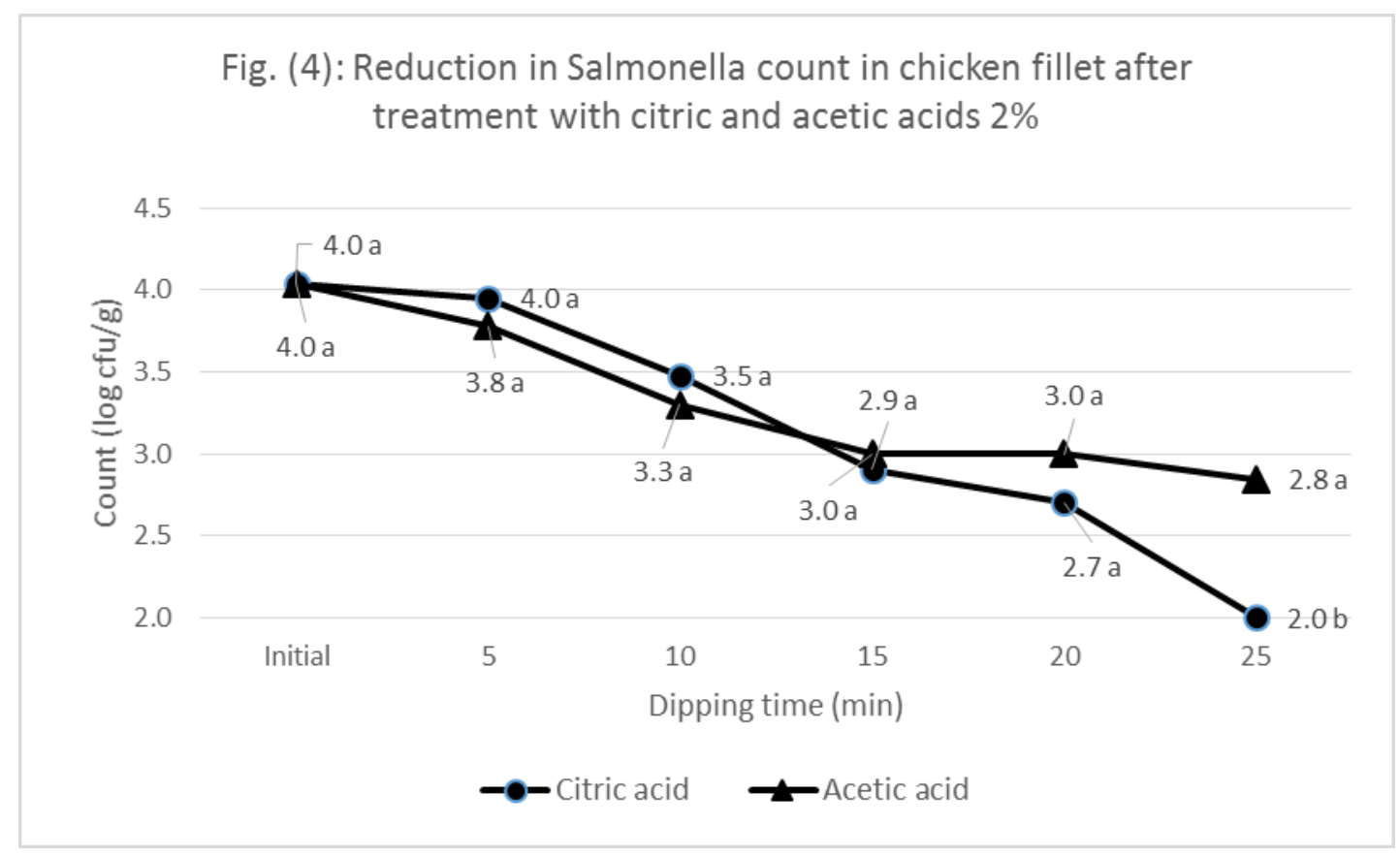

There are significance differences between means have same capital and small litter $(\mathrm{P}<0.01)$ for the same time. 


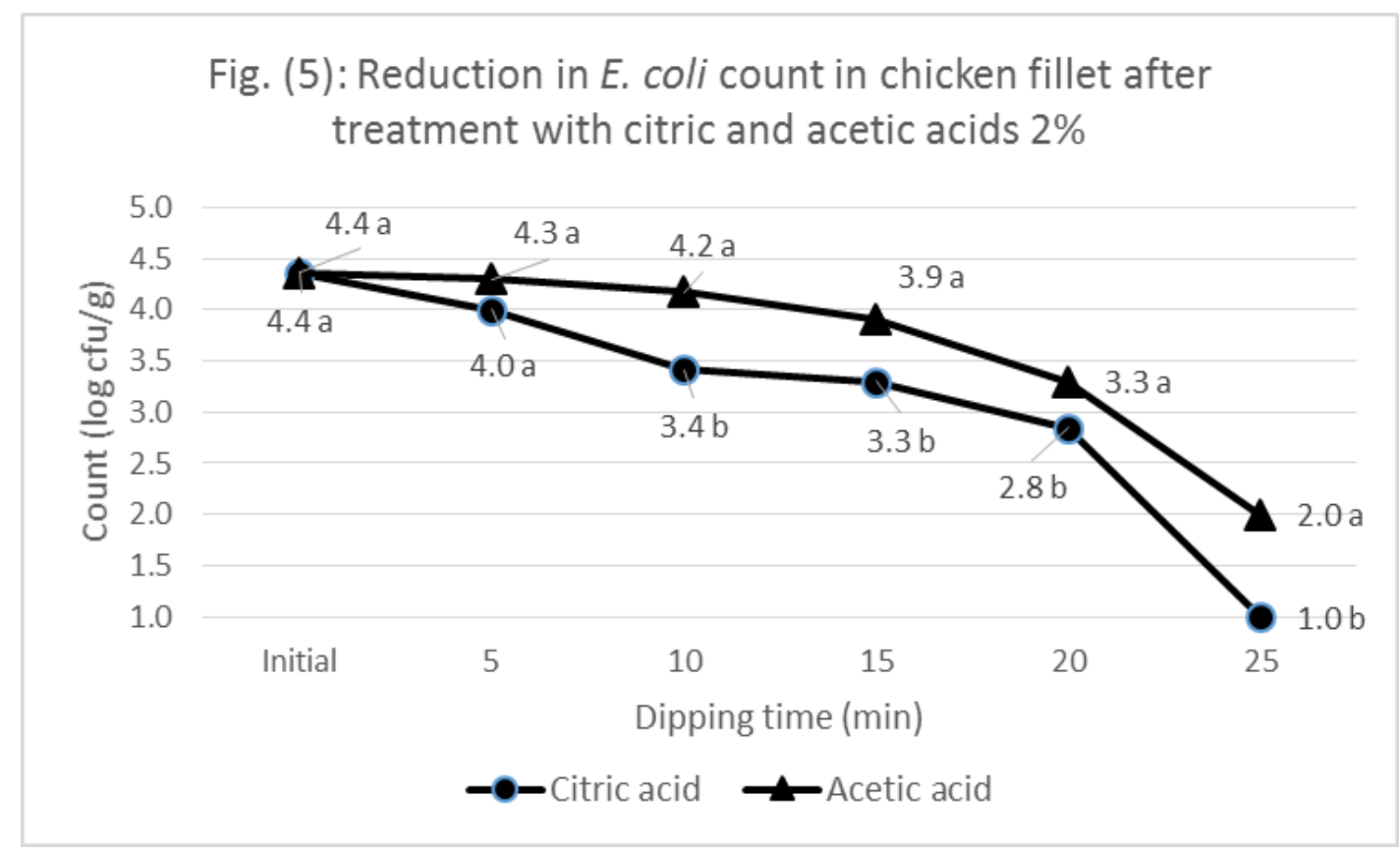

There are significance differences between means have same capital and small litter $(\mathrm{P}<0.01)$ for the same time.

Regarding salmonella inoculated chicken fillet (Fig. 4), the initial count before treatment was $4 \log \mathrm{cfu} / \mathrm{g}$, which begin to reduce after treatment for $10 \mathrm{~min}$. the reduction reached one $\log \mathrm{cfu} / \mathrm{g}$ after $15 \mathrm{~min}$ without significance difference $(\mathrm{P}>0.05)$ between the two treatments. On the other hand, after dipping for 25 min, citric acid treatment significantly $(\mathrm{P}<0.05)$ produced more reduction in salmonella count than acetic acid to reach $2 \log$ reduction than the initial count comparing to $1.2 \log$ for acetic acid.

For E. coli inoculated chicken fillet (Fig. 5), the initial count before treatment was $4.4 \log \mathrm{cfu} / \mathrm{g}$. Citric acid treatment reduced the count significantly $(\mathrm{P}<0.05)$ more than acetic acid beginning from 10 min dipping time as it reduced the count by one $\log$ cfu/g after $10 \mathrm{~min}$. After $25 \mathrm{~min}$ of dipping, citric acid reduced $E$. coli count by $3.3 \log \mathrm{cfu} / \mathrm{g}$, while acetic acid reduced the count to a lesser extent $(\mathrm{P}<0.05)(2.4 \log \mathrm{cfu} / \mathrm{g})$.

\section{DISCUSSION}

The initial microbial load depends on the physiological status of the animal at slaughter, the spread of contamination into slaughterhouses and during processing, while temperature and other conditions of storage during distribution can also influence the rate of spoilage (Nychas et al., 2008). Concerning the bacterial count nearly similar results were obtained by Daoud et al. (2012) for coliforms count (1.7 log cfu/g); Kozačinski (2006) and Odwar et al. (2014) for breast meat and a little bit higher results were recorded by Shawish (2011) (5 log $\mathrm{cfu} / \mathrm{g})$. Meanwhile, lower results were recorded by
Haleem et al. (2013) (3.45 log cfu/g in thigh and 2.33 cfu/g in breast meat), Odwar et al. (2014) and Daoud et al. (2012) $3.3 \log \mathrm{cfu} / \mathrm{g}$ for APC. On the other hand, higher results were recorded for APC by AlDughaym and Altabari (2010), Azab (2013) (7.33 log $\mathrm{cfu} / \mathrm{g})$ and Ibrahim et al. (2014) (6.7 log cfu/g) and for coliform Haleem et al. (2013) (2.3 log cfu/g in thigh and $3.1 \mathrm{cfu} / \mathrm{g}$ in breast meat).

High levels of bacteria and microorganism in food products can potentially generate undesirable deteriorations in flavor, odor, color, sensory, and textural properties and may even become harmful to human health (Raouche et al., 2011). The higher content of microbial flora in thigh than breast may be attributed to high content of fat in thigh as compared with breast (Haleem et al., 2013). Also thigh need more hand work than breast which lead to more contamination from the work environment and workers' hands.

Concerning Salmonella isolation, nearly similar results were obtained by Anju et al. (2014) (4.44\%) and Shawish (2011) (4.3\%), while Haleem et al. (2013) didn't isolated any salmonella strains from both thigh and breast meat. On the other hand, higher incidence were recorded by Kozačinski (2006) (10.60\%); Freitas et al. (2010) (10\%); Thai et al. (2012) (38.8\%) and Saeed et al. (2013) (22\%).

Regarding E. coli, nearly similar results were recorded by Suthienkul et al. (1990) (9\%) for breast, Schaumburg et al. (2014) (23\%) and Akbar et al. (2014) (25\%) for thigh, but somewhat higher results were recorded by Zhao et al. (2001) (38\%) and Bhattacharjee et al. (1996) (41\%). On the other hand 
very higher results were recorded by Hossain et al. (2008) (60\%) and Odwar et al. (2014) (78\%).

Concerning S. aureus, nearly the same results were recorded by Schaumburg et al. (2014) (3\%), while lower results were recorded by Lin et al. (2009) $(0.3 \%$ and $0.4 \%)$. On the other hand, higher and very higher results were obtained by Hanson et al. (2011) (17.8\%), Shawish (2011) (21.4\%), Kozačinski (2006) (30.30\%), Martins et al. (2013) (62\%) and Kitai et al. (2005) (65.8\%).

Not only can $S$. aureus enter the process on raw materials, but it can also be introduced into foods during processing from unclean hands and unsanitary utensils and equipment. The hazard develops into toxin formation when raw materials and products are exposed to temperatures between $10^{\circ} \mathrm{C}$ and $21.1^{\circ} \mathrm{C}$ for more than $12 \mathrm{~h}$ or to temperatures greater than $21.1^{\circ} \mathrm{C}$ for more than $3 \mathrm{~h}$ (FDA, 2001).

Concerning the overall fitness Odwar et al. (2014) found that $76 \%$ of chicken meat samples fall under the unacceptable coliforms count limit. On the contrary of our results, Shawish (2011) and Azab (2013) didn't find any significant difference between thigh and breast.

Concerning the reduction in APC and pathogenic microorganisms, similar results were obtained by Min et al. (2007) and Frederick et al. (1994) who used 2\% acetic acid to reduce APC and coliforms count by about $1 \log \mathrm{cfu} / \mathrm{g}$. Meanwhile higher reduction rates were recorded by Hamby et al. (1987) (1.8 to 4.3 $\log / \mathrm{cm}^{2}$ ), Min et al. (2007) who reported $3 \mathrm{log} \mathrm{cfu} / \mathrm{g}$ reduction using citric acid and Menconi et al. (2013) (more than $6 \mathrm{log} /$ section).

Similarly, Tamblyn and Conner (1997) recorded 1.9 $\log$ reduction in $S$. Typhimurium count using citric acid (4\%). Meanwhile, $2 \%$ acetic acid significantly reduced Salmonella according to Frederick et al. (1994) this reduction was 0.5 to $0.8 \log \mathrm{CFU} / \mathrm{cm}^{2}$ according to Dickson (1992). Menconi et al. (2013) reported a significant reduction in $S$. Typhimurium and E. coli $\mathrm{O} 157: \mathrm{H} 7$ (3.8 and $3.2 \mathrm{log} \mathrm{cfu} / \mathrm{g}$ ) using $0.8 \%$ organic acid combination.

Both of citric and acetic acids $2 \%$ proved to be effective as decontaminant in chicken fillet against $S$. aureus and E. coli by reducing more than $2 \log \mathrm{cfu} / \mathrm{g}$ of count. Meanwhile, citric acid was effective in reducing salmonella by $2 \log \mathrm{cfu} / \mathrm{g}$, acetic acid reduced $1.2 \log \mathrm{cfu} / \mathrm{g}$. both acids reduced the APC by only one $\log \mathrm{cfu} / \mathrm{g}$. According to Jetton et al. (1992) carcass rinse applications that decrease count by $2 \mathrm{log}$ are considered effective.

In comparison between acetic and citric acids in the same concentration, there was no significance difference between them in reduction of APC and $S$. aureus, but the later was more effective $(\mathrm{P}<0.05)$ in controlling both of $E$. coli and salmonella. These results agree with that obtained by Parveen et al. (2007) who found that lactic and citric acids at concentrations of 1 to $3 \%$ have been shown to reduce E. coli O157:H7, and Salmonella serotypes when sprayed on beef and poultry carcasses by causing intracellular acidification. Citric acid showed to have the highest inhibitory effect because of its ability to diffuse through the cell membrane.

On the contrary of this Seoknam et al. (2003) and ElKhawas and Hassan (2015) reported that acetic acid was more effective than citric acid. This difference may be due to the different medium used. Foster and Hall (1990) mentioned that difference between the effect of acetic and citric acids may be referred to that, lethal effects of these weak acids depend on concentration, $\mathrm{pH}$ of the environment and the dissociation constant of each acid beside adapted or resistant strains due to sub-lethal conditions.

\section{REFERENCES}

Aberle, E.D.; Forrest, J.C.; Gerrard, D.E. and Mills, E.W. (2001): Principles of Meat Science. $4^{\text {th }}$ ed. Kendall/Hunt Publishing Co., Dubuque, IA.

Acuff, G.R. (2005): Chemical decontamination strategies for meat. In J. N. Sofos (Ed.), Improving the safety of fresh meat (pp. 350363). Boca Raton, FL: CRC Press.

Akbar, A.; Uzma Sitara; Shabir Ahmed khan; Imran Ali; Muhammad Iftikhar Khan; Tanrawee Phadungchob and Anil Kumar Anal (2014): Presence of Escherichia coli in poultry meat: A potential food safety threat. Int. Food Res. J. 21(3): 941-945.

Al-Dughaym, A.M. and Altabari, G.F. (2010): Safety and quality of some chicken meat products in Al-Ahsa markets-Saudi Arabia. Saudi J. of Biological Sci., 17: 37-42.

Anju, P.; Latha, C.; Sunil, B. and Sethulekshmi, C. (2014): Detection of Salmonella and Yersinia spp. in uncooked retail chicken meat in Kerala by multiplex PCR. Int. J. Curr. Microbiol. App. Sci 3(6) 1028-1034.

APHA (2001): Compendium of Methods for the Microbiological Examination of Foods. Downes, F. P. and Ito, K. (eds.). $4^{\text {th }}$ ed. American Public Health Association, Washington, DC. USA.

Azab, R.M. (2013): Studies On Chicken Meat Quality In Relation To Veterinary Education. Ph.D.

Thesis, Zagazig University. Faculty of Veterinary Medicine. Department of Food Control, Meat Hygiene.

Bean, N.N. and Griffin, P.M. (1990): Food borne disease outbreaks in the United States, 1973- 
1987; pathogens, vehicles and trends. J. Food Prot. 53, 804-817.

Beuchat, L.R.; Ryu, J.H.; Adler, B.B. and Harrison, M.D. (2006): Death of Salmonella, Escherichia coli O157:H7, and Listeria monocytogenes in shelf-stable, dairy based, pourable salad dressings. J. Food Prot., 69: 801-814.

Bhattacharjee, P.S.; Kundu, R.L.; Biswas, R.K.; Mazumder, J.U.; Hossain, E. and Miah, A.H. (1996): A retrospective analysis of chicken diseases diagnosed at the central disease investigation laboratory, Dhaka, Bangladesh. Bangladesh J. Microbiol 30: 105-113.

Capita, R.; Alonso-Calleja, C.; Garcia-Arias, M.T.; Moreno, B.; Del Camino Garcia-Fernandez, M. (2002): Methods to detect the occurrence of various indicator bacteria on the surface of retail poultry in Spain. J. Food Sci. 67, 765771.

Chang, W.S.; Afsah-Hejri, L.; Rukayadi, Y.; Khatib, A.; Lye, Y.L.; Loo, Y.Y.; Mohd Shahril, N.; Puspanadan, S.; Kuan, C.H.; Goh, S.G.; John, Y.H.T.; Nakaguchi, Y.; Nishibuchi, M. and Son, R. (2013): Quantification of Escherichia coli O157:H7 in organic vegetables and chickens. Int. Food Res. J. 20 (2): 1023-1029.

Corry, J.E.L.; James, S.J.; Purnell, G.; BarbedoPinto, C.S.; Chochois, Y.; Howell, M. and James, C. (2007): Surface pasteurization of chicken carcasses using hot water. J. Food Eng. 79: 913-919.

Daoud, J.R.; Farghaly, R.M. and Maky, M. (2012): Microbial quality of frozen chicken meat at grocerystores in Qena city. J. Food Process Technol, 3: 187.

Dickson, J.S. (1992): Acetic acid action on beef tissue surfaces contaminated with Salmonella typhimurium. Journal of Food Science, 57, 297-301.

Do Carmo, L.S.; Cummings, C.; Linardi, V.R.; Dias, R.S.; De Suoza, J.M.; De Sena, M.J.; Dos Santos, D.A.; Shupp, J.W.; Pereira, R.K. and Jett, M. (2004): A cause of massive staphylococcal food poisoning incident. Foodborne Pathog. Dis. 1:241-246.

Egyptian Standards (2005): ES No. 1090 for frozen poultry and rabbits. Egyptian Organization for Standardization and Quality, Arab Republic of Egypt.

El-Khawas, K.M. and Hassaan, H.M. (2015): Control of food poisoning bacteria during manufacturing of acid cheese using some organic acids. Assiut Vet. Med. J. 61 (145): 40-46.

FDA (Food and Drug Administration Center for Food Safety \& Applied Nutrition) (2001): Staphylococcus aureus toxin formation in hydrated batter mixes, p. 201-208. In Fish and fisheries products hazards and controls guidance, $3^{\text {rd }}$ ed. Food and Drug Administration Center for Food Safety \& Applied Nutrition, Washington, D.C.

Fearnley, E.; Raupach, J.; Lagala, F. and Cameron, $S$. (2011): Salmonella in chicken meat, eggs and humans; Adelaide, South Australia, 2008. Int. J. Food Microbiol. 146: 219-227.

Foster, J.W. and Hall, H.K. (1990): Adaptive acidification tolerance response of Salmonella Typhimurium. J. Bacteriol., 172: 771-778.

Frederick, T.L.; Miller, M.F.; Thompson, L.D. and Ramsey, C.B. (1994): Microbiological properties of pork cheek meat as affected by acetic acid and temperature. Journal of Food Science, 59, 300-305.

Freitas, C.G.; Santana, A.P.; Silva, P.H.C.; Goncalves, V.S.P.; Barros, M.A.F.; Torres, F.A.G.; Murata, L.S. and Perecmanis, S. (2010): PCR multiplex for detection of Salmonella enteritidis, Typhi and Typhimurium and occurrence in poultry meat. Int. J. Food Microbiol. 139: 15-22.

Fries, R. (2002): Reducing Salmonella transfer during industrial poultry meat production. World Poultry Sci. J. 58, 527-540.

Haleem, A.M.; Al-Bakri, S.A. and Al-Hiyaly, S.A.K. (2013): Determination of Microbial Content in Poultry Meat in Local Iraqi Markets. J. Microbiol. Res., 3(6): 205-207.

Hamby, P.L.; Savell, J.W.; Acuff, G.R.; Vanderzant, C. and Cross, H.R. (1987): Spraychilling and carcass decontamination systems using lactic and acetic acid. Meat Science, 21, 1-14.

Hanson, B.M.; Dressler, A.E.; Harper, A.L.; Scheibel, R.P.; Wardyn, S.E.; Roberts, L.K.; Kroeger, J.S. and Smith, T.C. (2011): Prevalence of Staphylococcus aureus and methicillin-resistant Staphylococcus aureus (MRSA) on retail meat in Iowa. J. Infect. Public Health 4(4): 169-174.

Hassanein, R.; Ali, S.F.H.; Abd El- Malek, A.M.; Mohamed, M.A. and Elsayh, K.I. (2011): Detection and identification of Salmonella species in minced beef and chicken meats by using Multiplex PCR in Assiut city. Vet. World. 4: 5-11.

Hinton, M.H. and Corry, J.E.L. (1999): The decontamination of carcass meat. Poultry meat science (pp. 285-296). Oxon: Cabi Publishing.

Hossain, M.T.; Siddique, M.P.; Hossain, F.M.A.; Zinnah, M.A.; Hossain, M.M.; Alam, M.K.; Rahman, M.T. and Choudhury, K.A. (2008): Isolation, identification, toxin profile and antibiogram of Escherichia coli isolated from broilers and layers in Mymensingh district of Bangladesh. Bangladesh J. Vet. Med. 6 (1): 01-05.

Huys, G.; D’Haene, K.; Eldere, J.V.; Holy, A. and Swings, J. (2005): Molecular diversity and characterization of tetracycline-resistant 
Staphylococcus aureus isolates from a poultry processing plant. Appl. Environ. Microbiol. 71: 574-579.

Ibrahim, H.M.; Salem, A.M. and Shanab, M.S. (2014): Quality evaluation of some locally manufactured chicken meat products. Benha Vet. Med. J., 26 (2): 143-149.

Jablonski, L.M. and Bohach, G.A. (1997): Staphylococcus aureus In: Food microbiology: fundamentals and frontiers. (Doyle, M.P., L.R. Beuchat, T.J. Montville, Eds.), American Society for Microbiology, Washington, D. C. 353-375.

Jetton, J.P.; Bilgili, S.F.; Conner, D.E.; Kotrola, J.S. and Reiber, M.A. (1992): Recovery of salmonellae from chilled broiler carcasses as affected by rinse media and enumeration method. J. Food Prot. 55: 329-332.

Kimura, AC; Reddy, V. and Marcus, R. (2004): Chicken consumption is a newly identified risk factor for sporadic Salmonellae enteric serotype enteritidis infections in the United State. Clin. Infect. Dis. 38: 244-252.

Kitai, S.; Shimizu, A.; Kawano, J.; Sato, E.; Nakano, C.; Kitagawa, H.; Fujio, K.; Matsumura, K.; Yasuda, R. and Inamoto, T. (2005): Prevalence and characterization of Staphylococcus aureus and enterotoxigenic Staphylococcus aureus in retail raw chicken meat throughout Japan. J. Vet. Med. Sci. 67:269

Kozačinski, L.; Hadžiosmanović, M. and Zdolec, $N$. (2006): Microbiological quality of poultry meat on the Croatian market. Veterinarski ARHIV 76 (4): 305-313,

Lin, J.; Yeh, K.-S.; Liu, H.-T. and Lin, J.-H. (2009):Staphylococcus aureus Isolated from Pork and Chicken Carcasses in Taiwan: Prevalence and Antimicrobial Susceptibility. Journal of Food Protection. 72:608-611.

Lynch, M.; Painter, J.; Woodruff, R.; Braden, C. and Centers for Disease Control and Prevention. (2006): Surveillance for foodborne disease outbreaks United States, 1998-2002. MMWR Surveill. Summ. 55: 1-42.

Mani-López, E.; García, H.S. and López-Malo, A. (2012): Organic acids as antimicrobials to control Salmonella in meat and poultry products. Food Res. Intern., 45: 713-721.

Martins, P.D.; de Almeida, T.T.; Basso, A.P.; de Moura, T.M.; Frazzon, J.; Tondo, E.C. and Frazzon, A.P. (2013): Coagulase-positive staphylococci isolated from chicken meat: pathogenic potential and vancomycin resistance. Foodborne Pathog. Dis. 10: 771-6.

Mead, G.C. and Dodd, C.E.R. (1990): Incidence, origin and significance of staphylococci on processed poultry. J. Appl. Bacteriol. Symp. Suppl. 19: 81S-91S.

Menconi, A.; Shivaramaiah; S. and G.R. Huff, et al. (2013): Effect of different concentrations of acetic, citric, and propionic acid dipping solutions on bacterial contamination of raw chicken skin. Poultry Science, 92: 2216-2220.

Min, J.S.1.; Lee, S.O.; Jang, A.J.C. and Lee, M. (2007): Control of microorganisms and reduction of biogenic amines in chicken breast and thigh by irradiation and organic acids. Poult. Sci., 86(9): 2034-41.

Mulder, R.W. (1999): Hygiene during transport, slaughter and processing. In: Poultry Meat Science. Poultry Science Symposium Series. Volume Twenty-five. Richardson and Mead (Eds.). CABI Publishing 1999, 277-285.

Nychas, G.J.E.; Skandamis, P.N. and Tassou, C.C. (2008): Koutsoumanis, K.P., Meat spoilage during distribution. Meat Science, 78, 77-89.

Odwar, J.A.; Kikuvi, G.; Kariuki, J.N. and Kariuki, S. (2014): "A cross-sectional study on the microbiological quality and safety of raw chicken meats sold in Nairobi, Kenya." BMC Res. Notes 7: 627.

Paiao, F.G.; Arisitides, L.G.A.; Murate, L.S.; VilasBoas, G.T.; Vilas- Boas, L.A. and Shimokomaki, M. (2013): Detection of Salmonella spp, Salmonella enteritidis and Typhimurium in naturally infected broiler chickens by a multiplex PCR based assay. Brazilian J. Microbiol. 44: 37-41.

Parveen, S.; Taabodi, M.; Schwarz, J.G.; Oscar, T.P.; Harter-Dennis, J. and White, D.G. (2007): Prevalence and antimicrobial resistance of Salmonella recovered from processed poultry. J. Food Prot. 70: 2466-2472.

Raouche, S.; Mauricio-Iglesias, M.; Peyron, S.; Guillard, V. and Gontard, N. (2011): Combined effect of high pressure treatment and anti-microbial bio-sourced materials on microorganisms' growth in model food during storage. Innov. Food Sci. Emerg. Technol., 12: 426.

Saeed, A.A.; Hasoon, M.F. and Mohammed, M.H. (2013): Isolation and Molecular Identification of Salmonella Typhimurium from Chicken Meat in Iraq. J. World's Poult. Res. 3(2): 6367.

Schaumburg, F.; Alabi, A.S.; Frielinghaus, L.; Grobusch, M.P.; Kock, R.; Becker, K.; Issifou, S.; Kremsner, P.G.; Peters, G. and Mellmann, A. (2014): The risk to import ESBL-producing Enterobacteriaceae and Staphylococcus aureus through chicken meat trade in Gabon. BMC Microbiol. 14:286.

Seoknam, K.; Aera, J.; Sang, O.L.; J.S. M.; Il, S.K. and Mooha, L. (2003): Effect of organic acids on microbial populations and Salmonella Typhimurium in pork loins. AsianAustralasian J. Animal Science, 16 (1): 96-99.

Shar, A.H.; Kazi, Y.F.; Kanhar, N.A.; Soomro, I.H.; Zia, S.M. and Ghumro, P.B. (2010): Drinking water quality in Rohri City, Sindh, Pakistan. 
African Journal of Biotechnology 9 (42): 71027107.

Shawish, R.R. (2011): Microbial Evaluation of Some Retailed Cut-Up Chicken And Poultry Meat Products. M.V.Sc. Thesis, Department of Food Hygiene and Control, Faculty of Veterinary Medicine, Menufia University, Sadat city branch.

Suppakul, P.; Miltz, J.; Sonneveld, K. and Bigger, S.W. (2003): Active packaging technologies with an emphasis on antimicrobial packaging and its applications. J. Food Sci.. 68, 2, 408.

Suthienkul, O.; Brown, J.E.; Seriwatana, J.; Tienthongdee, S.; Sastravaha, S. and Echeverria, P. (1990): Shiga-Like-ToxinProducing Escherichia coli in retail meat and cattle in Thailand. Appl. Environ. Microbiol. 56 (4): 1135-1139.

Tamblyn, K.C. and Conner, D.E. (1997): Bactericidal activity of organic acids against Salmonella typhimurium attached to broiler chicken skin. Journal of Food Protection, 60, 623-633.

Tan, S.L.; Lee, H.Y.; Abu Bakar, F.; Abdul Karim, M.S.; Rukayadi, Y. and Mahyudin, N.A. (2013): Microbiological quality on food handlers' hands at primary schools in Hulu Langat District, Malaysia. Int. Food Res. J. 20 (5): 2973-2977.

Thai, T.H.; Hirai, T.; Lan, N.T. and Yamaguchi, R. (2012): Antibiotic resistance profiles of
Salmonella serovars isolated from retail pork and chicken meat in North Vietnam. Int. J. Food Microbiol. 156: 147151.

U.S. Department of Agriculture-National Organic Program (2008): Production and handling preamble.

Available at:http://www.ams.usda.gov/nop/NOP/standard s/Pro- dHandP-re.html. Accessed 20 February, 2015.

Wells, J.G.; Davis, B.R.; Wacsmuth, I.K.; Riley, L.W.; Remis, R.S.; Sokolow, R. and Morris, G.K. (1983): laboratory investigation of hemorrhagic colitis outbreaks associated with a rare Escherichia coli serotype. J. Clin. Microbiol., 18: 512-520.

WHO (2000): Food-borne disease: a focus for health education. $1^{\text {st }}$ ed. World Health Organization, Geneva.

Wilfred, R.S.; Nithin, P.K. and Naveen, K.G.S. (2012): Prevalence of food borne pathogens in market samples of chicken meat in Bangalore. Int. Food Res. J. 19 (4): 1763-1765.

Zhao, C.; Ge, B.; Juan, D.V.; Robert, S.; Emily, Y.; Shaohua, Z.; David, G.W.; David, W. and Jianghong, M. (2001): Prevalence of Campylobacter spp., Escherichia coli, and Salmonella serovars in retail chicken, turkey, pork, and beef from the greater Washington, D.C., Area. Appl. Environ. Microbiol. 67 (12): 5431-5436.

\section{الوقوف على الحالة الصحية لفيليه الدواجن المنتج في مجازر الدواجن وتحسينها باستخدام الاحماض العضوية من مصنادر طبيعية منية}

\section{خالل محمد سبا الخواص ، باسعة /حمد سعبل}

Email: kkhwas@yahoo.com

Assiut University web-site: www.aun.edu.eg

أجريت هذه الدراسة أولا بغرض تقصى الحالة البكتيرية لفيليه الداوجن المنتج فى هذه المجازر وثانيا لمحاولة تحسين تلك الحالة

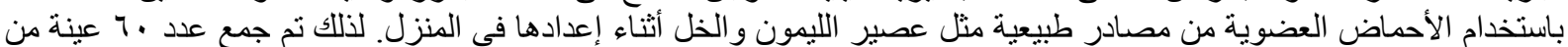

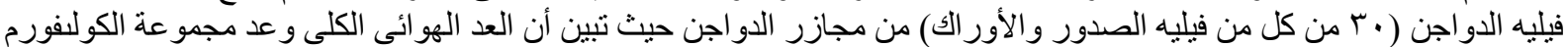

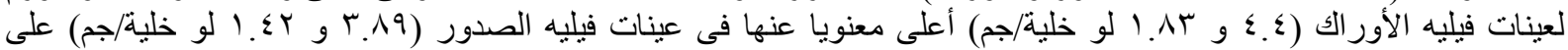

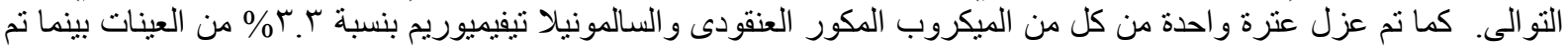

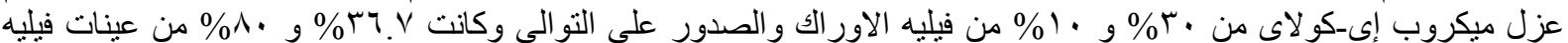

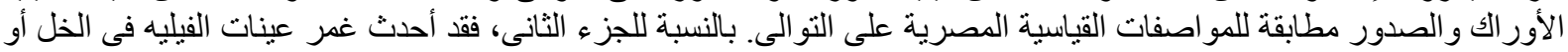

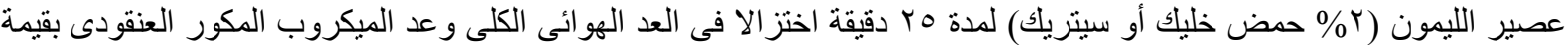

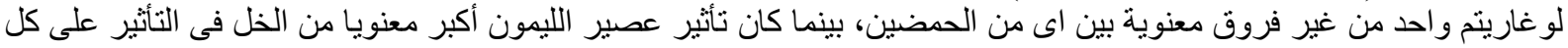

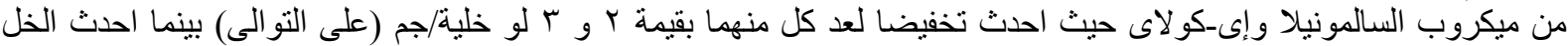

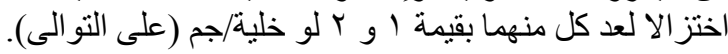

الكلمات الدالة: فيليه الدواجن، إى-كولاى، السالمونيلا، المكور العنقودى، الخل، عصبر الليمون 